\title{
International Relations at the Beginning of the XX Century in the Works of Vladimir Mikhailovich Khvostov
}

\author{
Albina Imamutdinova ${ }^{1^{*}}$ \\ Nikita Kuvshinov² \\ Elena Andreeva ${ }^{1}$ \\ Elena Venidiktova ${ }^{1}$ \\ ${ }^{1}$ Kazan Federal University \\ ${ }^{2}$ Kazan State Power Engineering Universities \\ ${ }^{*}$ Corresponding Author
}

Doi: 10.36941/jesr-2019-0027

\section{Abstract}

The article discusses the research activities of Vladimir Mikhailovich Khvostov, his creative legacy on issues and problems of international relations of the early XX century; the life of V.M. Khvostov, characterization and evolution of his approaches and views on the history of international relations, foreign policy. A prominent organizer and theorist in the field of pedagogical Sciences, academician Vladimir Mikhailovich Khvostov played a significant role in the formation of the Academy of pedagogical Sciences of the USSR - the all-Union center of pedagogical thought. As its first President, he paid great attention to the development and improvement of the system of humanitarian education in the school, taking into account all the tasks and requirements imposed by the practice of Communist construction in our country. In his reports and speeches at various scientific sessions and conferences, he repeatedly emphasized the exceptional importance of social Sciences in the training of not only educated girls and boys, but also in the formation of politically literate youth.

Keywords: history, historiography, history of international relations, international relations at the beginning of the XX century

\section{Introduction}

Vladimir Mikhailovich Khvostov (1905-1972) - graduate of the Eastern Pedagogical Institute (Khvostov, 1963) (now Kazan Federal University), historian, teacher, public figure.

Being the son of a famous historian in the field of ancient history, a professor at Kazan University, Mikhail Mikhailovich Khvostov (Sinitzyn \& Imamutdinova, 2015), he began his research and teaching activities in Kazan where he was recruited in 1924 to workers' faculty of Kazan State University (ARAS, 1667). In 1926, Vladimir Mikhailovich Khvostov moved to Moscow and entered graduate school at the Institute of History of the Russian Association of Research Institutes of Social Sciences which he successfully graduated in 1929 (Sinitzyn \& Imamutdinova, 2015).

In 1937, at a meeting of the Council of Moscow State University, the young specialist was awarded the academic title of professor (in the field of new history) (ARAS, 1667). Vladimir Mikhailovich conducted teaching in such educational institutions as the Moscow Institute of History, Philosophy and Literature named after N.G. Chernyshevsky, Moscow State University, Smolensk State Pedagogical Institute, Industrial Pedagogical Institute named after K. Liebknecht and others 
(Archive of the Russian Academy of Sciences, 1667).

V.M. Khvostov conducted scientific work in the field of new history, mainly on the history of diplomacy and international relations. From 1933 to 1938 he worked on his doctoral thesis «Essays on the foreign policy of the German Empire». In his work, he examines the main aspects and tendencies of the foreign policy of Germany in the last years of Bismarck's chancellorship.

\section{Methods}

The main methods of research were both General scientific methods (analysis and synthesis, induction and deduction) and special historical ones The global trend towards a free-trade-based development model and increased exports has led regional and transnational countries to step up their cooperation in trade and industry as an efficient tool for economic and social development. Accordingly, the Economic Cooperation Organization (ECO) has taken into account the economic development of member states. Since joining Azerbaijan, Uzbekistan, Tajikistan, Turkmenistan and Kyrgyzstan to its three founding countries (Iran, Turkey and Pakistan), the organization has received more attention. The most important role of the eco for member states is to develop its economic relations. However, it faces many economic and political obstacles.

\section{Results and Discussion}

The history of international relations has become one of the priority scientific topics for Vladimir Mikhailovich. Vladimir Khvostov often visited the reading room of the Archives of Foreign Policy of Russia of the USSR Ministry of Foreign Affairs, where he got acquainted with the documents of the foreign policy department of Tsarist Russia, diplomatic correspondence, reports and diaries of Russian diplomats.

Even before World War II V.M. Khvostov published a number of informative scientific articles on international relations in Europe and the Middle East, and also wrote about the policies of the European powers in this region. Vladimir Mikhailovich turned to the issues of international relations of European countries of the late XIX - early XX centuries. He paid special attention to the history of foreign policy of Kaiser Germany. The scientist published the results of a study of the Middle East crisis (1895 - 1897-ies), Bismarck's foreign policy, preparation for the capture of the Bosphorus in the 90 -ies of the XIX century. In addition to these works, Vladimir Khvostov published materials on the history of the Italian colonial expansion and the Italian-Abyssinian war (1895-1896-ies) and so on. He paid special attention to the publication of documents on the history of international relations that he had revealed in various archives. During this period, the historian wrote critical reviews of the works of foreign historians on Russia's foreign policy (Dunaevsky, 1974).

Drawing on a variety of documentaries Vladimir Mikhailovich gave his own description of the Franco-German relations after the Treaty of Frankfurt. He made a conclusion about continuous provocation of war against France by Bismarck, his desire to cause a new military conflict in any way. V.M. Khvostov showed a deep conviction of the German Chancellor that the new FrancoGerman war was inevitable. With good reason Vladimir Mikhailovich connected this issue with another central problem of European politics of the same period - Russian-German relations. He comprehensively analyzed the German-Austrian and German-Russian relations. Vladimir Khvostov reflected his views in the book "Bismarck's foreign policy crisis» (Khvostov, 1934) where he noted that the Austro-German alliance became «the core of the foreign policy» of the German Empire. That is why Germany sought to preserve the inviolability of the Austro-Hungarian monarchy.

As for the German-Russian relations, in the opinion of V.M. Khvostov, Bismarck, on the one hand, sought to keep Russia from an alliance with France by all means, and on the other hand, in every possible way pushed it on the slippery path of adventures in the Eastern question. The second path led to the inevitable clash between Russia and England. From this followed a very important conclusion of Vladimir Mikhailovich Khvostov: «Only in the light of the «English» policy of Bismarck is the true meaning of his policy towards Russia and Austria revealed» (Dunaevsky, 1974).

V.M. Khvostov also studied a complex tangle of current contradictions in the Middle East. 
Noting quite active actions of Russian diplomacy in the Balkans, he saw this as one of the reasons for Anglo-Russian antagonism.

Work on archival documents relating to the topical questions of European politics of the second half of the XIX century, led the scholar to study the policies of European powers and the United States at the beginning of the XX century, as well as subjects related to the history of the countries of Asia, Africa and Latin America in modern times. The result of the scholar's years of work was a chapter in the second volume of «The history of diplomacy» (first edition), devoted to the diplomatic history of the period 1870-1914. For this work he was awarded the State prize like several other authors of the book. V.M. Khvostov paid much attention to the initial period of the First World War and international relations during the war years, especially the foreign policy of Germany.

Despite the great lecture and propaganda burden, he continues to work on the second edition of "The history of diplomacy», the second volume of which «Diplomacy in modern times. 18011914» - was written entirely by him. He significantly revised and expanded his chapter, published in the first edition, attracted a huge array of additional documentary materials and sources.

In the 2nd edition of «The history of diplomacy» (V. II) V.M. Khvostov highlighted the nature of Russia's foreign policy. Two chapters were devoted to World War I: the twelfth and thirteenth (Khvostov, 1963). In preparing this publication, new research and publication of sources were taken into account, some inaccuracies were corrected, some sections were supplemented. At the same time the task was to overcome, whenever possible, the well-known one-sidedness of the first edition which mainly paid attention to European countries. For these purpose additional materials on the history of diplomacy in Asia, especially in China and India were included. The history of diplomacy of the United States of America has been significantly expanded.

So, in 1963, the second edition of the second volume of "The History of diplomacy» was published, considerably revised and expanded. It summed up the great work done by Soviet historians, and first of all, by Vladimir Mikhailovich himself. The volume was essentially a new job. It combined the research built on primary sources, the study of diplomatic actions and an in-depth analysis of the most important international phenomena and the foreign policy of Russia with broad generalizations.

It is necessary to note the work of Vladimir Mikhailovich entitled «Problems of the history of the USSR foreign policy and international relations. Selected works» (Khvostov, 1976). The book considered the formation and development of the Soviet historiography of modern times of Western countries in the first quarter of a century of the existence of the Soviet state. The monograph was based on numerous literature and archival documents extracted from the funds of 15 archives of the country. The author paid special attention to the analysis of the works of V.I. Lenin on the subject under study, the work of Soviet scientists on the new history of Western countries, the discussions on these problems, which took place in the second half of the 20 s - early $30 \mathrm{~s}$, the development of Soviet historical institutions. However, the book does not claim to provide comprehensive coverage of the questions posed.

In 1947, V.M. Khvostov published the same name work for the Supreme All-Army military and political courses of the Main Political Directorate of the Armed Forces of the USSR (Khvostov, 1940; Nigmatullin, 2007). The course was prepared for the period 1871-1917, consisted of 7 chapters («Franco-Prussian War and its consequences», "Eastern crisis of 1875-1878», "The emergence of two military-political blocs on the continent of Europe», "Completion of the struggle for repartition of the world and the first wars for this repartition», "Russian-Japanese War and Entente», «Fighting of Entente and German-Austrian Bloc (1908-1911)» and «Beginning of the First World Imperialist War».

\section{Conclusions}

The history of the First World War attracted attention of many researchers in various countries of the world. State and public figures, civil and military historians, writers and journalists, economists and sociologists devoted their works to it. An extensive literature has been created in which such cardinal questions as the origin, results and lessons of the war of 1914-1918, its impact on the 
economy and social and political life of the warring powers, the role of each participant, the nature of military operations and military art are analyzed and evaluated. The study of the First World War has not lost its relevance in our days because it is directly connected with the solution of one of the most pressing problems of modernity - the problem of war and peace. A generation of people living in an age of nuclear weapons turns to the past in order to better understand the present. And it is not without interest to know how in the second decade of the $X X$ century the imperialists managed to plunge the people into one of the greatest tragedies of human history. V.M. Khvostov tried to give his answer to these questions, devoting his doctoral thesis to this problem, numerous sections of "The history of diplomacy» and special articles.

\section{Acknowledgements}

The work is performed according to the Russian Government Program of Competitive Growth of Kazan Federal University.

\section{References}

ARAS, f. (1667). op. 1, folder 297. - 15 p.

ARAS, f. (1667). op. 1, folder 298. - 19 p.

ARAS, f. (1667). op. 1, folder 308. - 74 p.

Archive of the Russian Academy of Sciences, f. (1667). op. 1, folder 336. - 92 p.

Dunaevsky, V. A. (1974). Soviet Historiography of New History of Western Countries (1917-1941). - M, - 315 p.

Khvostov, V. M. (1934). Bismarck's foreign policy crisis. Marxist historian, 3, 31-79.

Khvostov, V. M. (1940). The History of International Relations and the Struggle for the Division of the World 1870-1900 (Study Guide). - M.: Military-political Academy named after Lenin, - 84 p.

Khvostov, V. M. (1963). The History of Diplomacy. 2nd Ed., V. 2. Diplomacy in modern times (1871-1914) /- M .: State Publishing House of Political Literature,. - $820 \mathrm{p}$.

Khvostov, V. M. (1976). Problems of the history of the USSR foreign policy and international relations. Selected works. - M .: Publishing House «Science», - 544 p.

Nigmatullin, R. Sh. (2007). Graduates of the Faculty of History of the Kazan State Pedagogical Institute (19181945). Kazan, 14-17. Essays on history and historical science in the USSR. V. 5 / Ex. ed. M.V. Nechkina. - M., 1985. - 413 p.

Sinitzyn, O. V., \& Imamutdinova, A. M. (2015). Generations in historical science: the Hvostovs dynasty. Journal of Sustainable Development, 8(7), August 2015, Special Issue, e-Version First TM / Canadian center of science and education. - Canada, 153-158. 